\title{
Effect of crusher dust on floristic composition and biological spectrum in tropical grassland of Odisha, India
}

\author{
B. K. Tripathy ${ }^{1}$, R. B. Mohanty ${ }^{2}$, N. Mishra ${ }^{3}$ and T. Panda ${ }^{4 *}$ \\ ${ }^{1}$ Department of Botany, Dharmasala Mohavidyalaya, Dharmasala,Jajpur, Odisha, India. \\ ${ }^{2}$ Department of Botany, N. C.Autonomous College, Jajpur, Odisha, India. \\ ${ }^{3}$ Department of Zoology, Chandbali College, Chandbali, Bhadrak-756133, Odisha, India. \\ ${ }^{4}$ Department of Botany, Chandbali College, Chandbali, Bhadrak-756133, Odisha, India.
}

Accepted 17 May, 2013

\begin{abstract}
An investigation was carried out to estimate the effect of crusher dust on floristic composition and biological spectrum in grassland of Odisha, India. The vegetation analysis was performed following standard procedures. The floristic survey of the study area, which includes natural as well as crusher unit affected sites, revealed the presence of 24 plant species distributed in 11 families representing a two storied floristic composition in the area. Out of the 24 species, maximum number of species belonged to the life-form class therophytes followed by hemi cryptophytes and chamaephytes and least number of species belonged to class geophytes. Some of the important families like Poaceae, Fabaceae, Cyperaceae and Convovulaceae are noted to be prevalent in the study area. The seasonal variation of relative frequency, relative density and relative dominance of different species fluctuated. The majority was from the species Aristida; the next two in order of dominance were Heteropogon and Setaria. The grass species have more IVI values as compared to non-grass species in the community. The value of Simpson's dominance index varied from 0.188 to 0.536 . It showed increasing trend from rainy to summer having highest value in summer. In contrary, the diversity index showed decreasing trend from rainy to summer.
\end{abstract}

Key words: Diversity indices, floristic composition, Jajpur district.

\section{INTRODUCTION}

The demand for basic necessities for survival and sustenance of life like food, water, air, etc, from natural resources is significantly increasing due to exponential growth of human population. Currently, India has taken major initiatives on developing the infrastructure, to meet the requirement of globalization in the construction of buildings and other structures; crusher unit plays a rightful role and is being utilized. In turn, land degradation due to the alteration and destruction of natural habitat is a major concern throughout the globe. The conversion of natural ecosystems into anthropo-ecosystems as a result of human activities is most apparent in and around urbanizing landscapes (Gupta and Narayan, 2010). The major factors responsible for land degradation is rapid urbanization, industrialization, unsustainable developmental projects and spread of mining activity which often results in the loss of natural ecosystems with associated biodiversity (Ezeaku and Davdson, 2008). The most affected part in this process was plants which is most sensitive and delicate in the environment of forest or grassland. In India, some 2500 species of total vascular flora fall in one or other category of threat (Jain, 1991); of these, the most prone are the angiosperms (Daniels and Jayathi, 1996). Grassland, one of the prominent 
ecosystems in earth's terrestrial surface area (approximately $1 / 3^{\text {rd }}$ ) is highly sensitive to change in environmental factors (Lalrammawia and Paliwal, 2010). Grassland biodiversity is considered as a natural (biomass) resource base of subsistence for the people of tropical countries. Therefore, loss of grassland very often jeopardizes economic progress in tropical regions. Grassland or forest degradation adversely affects soil physico-chemical and microbiological characteristics and thereby alters the nutrient status of the soil that lead to the genesis of barren degraded wasteland (Mroz et al., 1985; Lal, 1989). The widespread existence of different dust producing units (cement, marble, stone, etc.) in the rural-urban fringes of the $3^{\text {rd }}$ world countries was found to be one of the important anthropogenic activities with a potential to alter not only the ecology but also the metabolic activities of flora, fauna of the surrounding soil and vegetation (Raina et al., 2008; Okita et al., 1996; Chowdhary and Rao, 1996; Pandey and Nand, 1995; Mishra et al., 1993; Somashekar et al., 1999). Particulate matter released during stone crushing is usually of relatively large size. The chemical composition of the dust is a homogenous mixture of oxides of calcium, potassium, silica and sodium, which settles into a head mass when it comes in contact with water (Raina et al., 2008). Stone crusher dust is extremely harmful to human health as well as the ecological health of the region (Pandey et al., 2002; Srivastava et al., 2005). Literature data indicated that when these particulate matters are deposited on vegetation, the plant growth is adversely affected (Chatter, 1991; Mishra et al., 1993; Pandey and Nanda, 1995; Kumar, 2000). There have been several reports on the floristic composition of slag dump, abandoned mines and mine tailings (Prach et al., 2001; Roy et al., 2002; Pyseket al., 2003; Remon et al., 2005; Singh, 2006; Padey and Maiti, 2008) and such studies emphasizes the role of particulate matter on vegetation structure. But reports on the floristic composition effected by crusher dusts from Odisha are still lacking. Dust emissions occur from many operations in the dust units viz. cutting, loading and transportation. Therefore, it was necessary to study the effect of dust on floristic composition. In the present study, we analyzed the diversity, distribution and change in species composition structure with particular reference to crusher dusts in tropical grassland of Orissa, India, so as to develop appropriate strategies for their protection and conservation.

\section{MATERIALS AND METHODS}

\section{Study site and its characteristics}

The present investigation was carried out in tropical grassland $\left(20^{\circ} 33^{\prime}-21^{\circ} 10^{\prime \prime} \mathrm{N}\right.$ and between $\left.85^{\circ} 40^{\prime}-86^{\circ} 44^{\prime \prime} \mathrm{E}\right)$ of Dharmasala locality and its adjoining areas under Darpani and Sukinda Tahasil, situated north-central region of the Jajpur district, Odisha, India, mostly in both sites of $\mathrm{NH}-5$ and $\mathrm{NH}-5 \mathrm{~A}$. Climate of the area is tropical monsoonic, experiencing three distinct seasons: rainy (mid June to mid October), winter (mid October to February) and summer (March to mid June). The air temperature ranges from $38^{\circ} \mathrm{C}$ in summer to $13^{\circ} \mathrm{C}$ in winter, with an annual average rainfall of approximately $1500 \mathrm{~mm}$. Soil of the area is red and laterite. The $\mathrm{pH}$ and average moisture content of the soil arwe recorded to be between 5.6 and 6.4 and 3.5 and $13 \%$, respectively.

Sukinda and Daitari are the two important hill ranges of the district. The hilly tracts with Lalitgiri, Udayagiri, Ratnagiri, Alamgiri, Bathuria-Khola, Phulajhar, Dalimbapani, Gobarghati, ChandikholMahavinayak, Olasuni, Langudi, Deuli, etc. rise up to $900 \mathrm{~m}$ above the sea level and contains thick and varied vegetation. In and around Dharmasala area, about 100 crusher units are operating in the vicinity of National highway No. 5 and 5 A (Daitay- Pradeep express highway) as the major small scale industries which fulfill the growing demand of urban expansion. These crusher units are established mainly adjacent to agricultural lands, grasslands, rice fields or village wastelands and using abundantly available granites of this area as raw material.

\section{Vegetation analysis}

The vegetation analysis was conducted during June 2008-May 2009 , to cover all the spectrum of vegetation. Two sites of about five hectare each were selected for the investigation. First one on the crusher dust effected grassland and the second about $5 \mathrm{~km}$ away without any crusher units. The life form classes were determined as per Raunkiaer's (1934). Random sampling method was adopted to sample the vegetation. Five separate plots were laid on each study sites. Ecological enumeration of plant species were done according to quadrate sampling method (Mishra, 1968). Each tiller was counted as an individual plant in case of grasses and each forbs was considered as an individual. However, in the case of runners, each node rooted at the base was considered as an independent individual. The size of the quadrate was $50 \times 50$ $\mathrm{cm}$. Vegetation data were quantitatively analysed for relative values of frequency, density and abundance (Phillips,1959).

Relative frequency $=$ (number of plots containing a species $/$ number of occurrences of all species) $\times 100$

Relative density = (number of individuals of a species / total number of individuals of all species) $\times 100$

Relative dominance $=($ basal area of a species $/$ total basal area of all species) $\times 100$

Importance value index (IVI) for individual plant species was determined as the sum of their relative frequency, relative density and relative dominance.

\section{Statistical analysis}

The following indices of diversity were calculated based on species level identification (Ludwig and Reynolds, 1988).

Shannon's species diversity $\left(H=-\sum\right.$ pi $/ n$ pi) where pi is the proportion of the total number of individuals / green biomass belonging to its $\mathrm{i}^{\text {th }}$ species, In denotes natural logarithm and and $\mathrm{H}$ is the Shannon-Wiener index.

Simpson's dominance indices $\left(D=\sum(n i / N)^{2}\right.$, where $n i$ is the density of species, that is, total number of individuals/green biomass of the species, $\mathrm{N}$ denotes total number of individuals or plant biomass of the same sample and D is the Simpson's index. 
Table 1. Floristic composition and respective life-form classes at experimental sites.

\begin{tabular}{|c|c|c|c|c|}
\hline $\mathbf{S} / \mathbf{N}$ & Name of the species & Grass/Forbs/Sedge/Shrub & Family & Life-form classes \\
\hline 1. & Aristida setacea Retz. & Grass & Poaceae & Hemicryptophytes \\
\hline 2. & Bothriochloa pertusa (L.) A. Camus & Grass & Poaceae & Hemicryptophytes \\
\hline 3. & Chrysopogon aciculatus (Retz.) Trin. & Grass & Poaceae & Hemicryptophytes \\
\hline 4. & Cynodon dactylon (L.) Pers. & Grass & Poaceae & Hemicryptophytes \\
\hline 5. & Cyperus rotundus L. & Sedge & Cyperaceae & Geophytes \\
\hline 6. & Cyperus nivenus Retz. & Sedge & Cyperaceae & Geophytes \\
\hline 7. & Digitaria ciliaris (Retz.) Koeler & Grass & Poaceae & Therophytes \\
\hline 8. & Eragrostis gangetica (Roxb.) Steud. & Grass & Poaceae & Therophytes \\
\hline 9. & Heteropogon contortus (L.) P. Beauv. & Grass & Poaceae & Hemicryptophytes \\
\hline 10. & Panicum repens $\mathrm{L}$. & Grass & Poaceae & Hemicryptophytes \\
\hline 11. & Setaria pumila (Poir.) Roem. \& Schult. & Grass & Poaceae & Therophytes \\
\hline 12. & Sporobolus indicus (L.) R. Br. & Grass & Poaceae & Therophytes \\
\hline 13. & Andrographis echioides (L.) Nees & Grass & Acanthaceae & Therophytes \\
\hline 14. & Cassia tora L. & Shrub & Caesalpiniaceae & Therophytes \\
\hline 15. & Celocia argentea L. & Forbs & Amaranthaceae & Therophytes \\
\hline 16. & Crotolaria prostrate Rottl. ex Willd & Shrub & Fabaceae & Therophytes \\
\hline 17. & Desmodium triflorum (L.) DC & Forbs & Fabaceae & Chamaephytes \\
\hline 18. & Evolvulus alsenoides (L.) L. & Forbs & Convolvulaceae & Chamaephytes \\
\hline 19. & Evolvulus numularius (L.) L. & Forbs & Convolvulaceae & Chamaephytes \\
\hline 20. & Phyllanthus virgatus Forst. $\mathrm{f}$. & Forbs & Euphorbiaceae & Chamaephytes \\
\hline 21. & Sida acuta Burm. f. & Forbs & Malvaceae & Chamaephytes \\
\hline 22. & Spermacoce hipsida L. & Grass & Rubiaceae & Chamaephytes \\
\hline 23. & Vernonia cinerea (L.) Less. & Forbs & Asteraceae & Therophytes \\
\hline 24. & Zornia gibbose Sponoghe & Forbs & Fabaceae & Therophytes \\
\hline
\end{tabular}

\section{RESULTS AND DISCUSSION}

The floristic survey of the study area, which includes natural as well as crusher unit affected sites, revealed the presence of 24 plant species distributed in 11 families representing a two storied floristic composition in the area (Table 1). The two storey's observed were consisting of shrubs (height range: 2 to $4 \mathrm{~m}$ ) and herbs of seasonal and perennial type. Out of the 24 species, maximum number of species belonged to the life-form class therophytes (10 species) followed by hemi cryptophytes and chamephytes (6 species each) and least number of species (02 species) belonged to class geophytes. It was observed that therophytes contributes maximally $(41.66 \%)$ followed by chamaephytes and hemicryptophytes with $25 \%$ each and geophytes with least percentage (8.33\%) (Figure 1). Since the percentages of chamephytes/hemicryptophytes is next to therophytes, the vegetation may be called therochamephytic.

The higher percentage of therophytes in the grassland was due to periodic climate change along with interference of crusher unit activities (Misra, 1978; Barik and Mishra, 1998). When comparing the present findings with Raunkiaer's (1934) normal spectrum, it was observed that the percentage contribution of therophytes was 28.66 times, chamaephytes- 16 times, geophytes4.33 times higher and hemicryptopytes was $1 \%$ less. However, the biological spectrum of the present study was found to be close to the findings of Pradhan (1994) and Misra and Mishra (1981). Among the grasses, Aristida setacea, Bothriochloa pertusa, Chrysopogon aciculatus, Heteropogon controtus and Andrographis echioides, among the sedge, Cassia tora and Demodium triflorum among forbs in either of the sites showed dominance during the study period (Table 2). All the species appeared with the onset of monsoon and completed their life-cycle towards the end of the winter season. The common occurrence of certain grasses, forbs, sedges and shrubs on both sites indicates their adaptability to thrive in adverse conditions of the waste material. Adaptability of some genera like Cyperus, Eragrostis and Evovulus to survive in coal mine area has already been reported by Ekka and Behera (2010).

Comparative analysis of the percentage contribution of different groups of plant species indicated the highest contribution by grasses, followed by forbs. Some of the important families like Poaceae, Fabaceae, Cyperaceae and Convovulaceae are noted to be prevalent in the study area. Poaceae is the dominant family and have been reported to play positive role as the initial colonizer of the different derelict mine soils (Helm, 1995; Singh, 


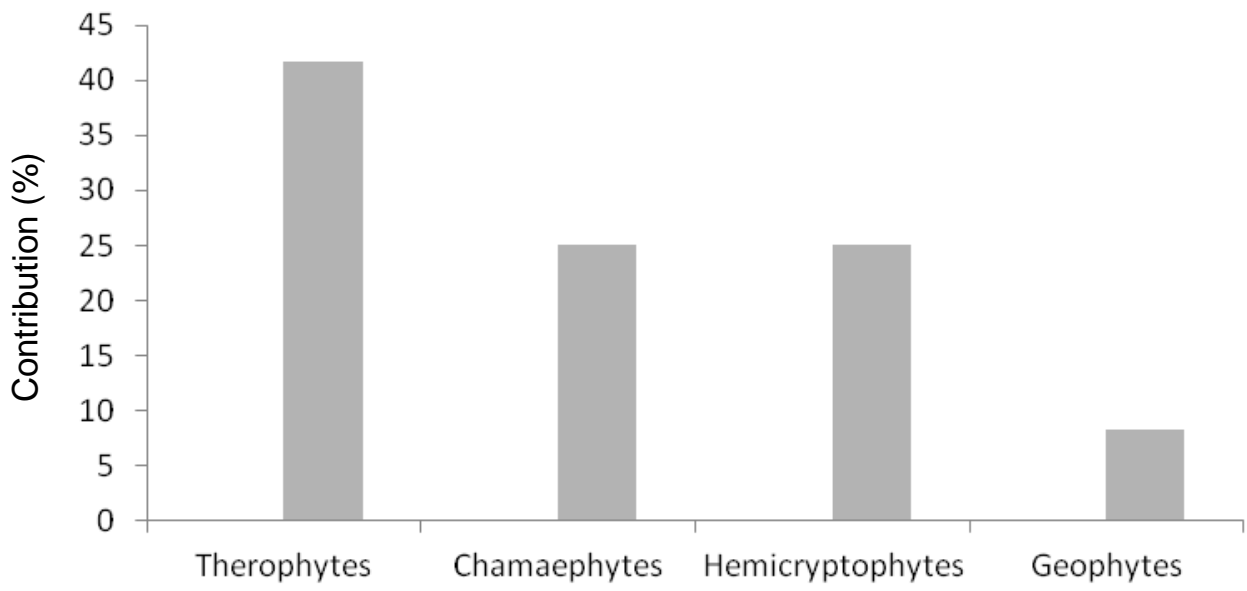

Life form class

Figure 1. Percentage contribution of different life form class.

Table 2. Seasonal variation of relative density and relative frequency of plant species at the study sites.

\begin{tabular}{|c|c|c|c|c|c|c|c|c|c|c|c|c|}
\hline \multirow{3}{*}{ Plant species } & \multicolumn{6}{|c|}{ Relative frequency } & \multicolumn{6}{|c|}{ Relative density } \\
\hline & \multicolumn{3}{|c|}{ Site1 } & \multicolumn{3}{|c|}{ Site2 } & \multicolumn{3}{|c|}{ Site1 } & \multicolumn{3}{|c|}{ Site2 } \\
\hline & $\mathbf{R}$ & $\mathbf{W}$ & $\mathrm{s}$ & $\mathbf{R}$ & $\mathbf{W}$ & s & $\mathbf{R}$ & $\mathbf{W}$ & S & $\mathbf{R}$ & $\mathbf{W}$ & s \\
\hline Aristida setacea & 5.09 & 5.55 & 10.58 & 5.39 & 5.93 & 12.1 & 16.51 & 19.97 & 38.3 & 18.53 & 24.22 & 42.25 \\
\hline Bothriochloa pertusa & 4.83 & 5.28 & 8.99 & 5.05 & 5.64 & 0.33 & 4.28 & 4.7 & 6.77 & 4.4 & 5.57 & 7.65 \\
\hline Chrysopogon aciculatus & 4.33 & 4.44 & 7.41 & 4.26 & 4.15 & 7.27 & 1.79 & 1.66 & 1.97 & 1.75 & 1.88 & 2.14 \\
\hline Cynodon dactylon & 4.33 & 4.44 & 4.76 & 4.23 & 4.45 & 3.64 & 4.27 & 4.087 & 2.07 & 4.37 & 4.19 & 1.22 \\
\hline Cyperus rotundus & 4.83 & 4.722 & 1.59 & 5.05 & 4.75 & 2.42 & 3.5 & 2.76 & 0.62 & 2.95 & 2.41 & 0.61 \\
\hline Cyperus nivenus & 4.58 & 4.72 & 2.12 & 4.25 & 4.75 & 2.42 & 2.84 & 2.25 & 1.14 & 2.75 & 2.28 & 0.77 \\
\hline Digitaria ciliaris & 3.82 & 3.61 & 1.59 & 3.72 & 3.56 & 1.82 & 2.13 & 1.35 & 1.55 & 2.06 & 1.61 & 1.22 \\
\hline Eragrostis gangetica & 4.07 & 3.89 & 1.06 & 4.52 & 5.64 & 1.21 & 3.2 & 3.58 & 4.72 & 3.05 & 3.27 & 4.16 \\
\hline Heteropogon contortus & 4.83 & 5.00 & 8.99 & 5.05 & 5.34 & 10.3 & 18.16 & 19.71 & 26.16 & 20.01 & 21.49 & 23.23 \\
\hline Panicum repens & 3.56 & 3.61 & - & 4.52 & 4.75 & - & 4.32 & 3.45 & - & 4.41 & 3.75 & - \\
\hline Setaria pumila & 4.58 & 4.72 & 6.88 & 3.72 & 3.56 & 4.24 & 18.38 & 21.43 & 11.92 & 16.68 & 17.42 & 9.78 \\
\hline Sporobolus indicus & 4.33 & 4.17 & 3.17 & 3.99 & 3.86 & 4.85 & 7.83 & 5.75 & 1.3 & 6.3 & 4.82 & 0.61 \\
\hline Andrographis echioides & 4.33 & 4.72 & 8.47 & 4.26 & 5.04 & 4.85 & 1.15 & 1.28 & 0.73 & 1.22 & 1.34 & 0.48 \\
\hline Cassia tora & 4.58 & 4.72 & 6.35 & 4.26 & 3.56 & 6.06 & 0.98 & 0.49 & - & 1.07 & 0.48 & - \\
\hline Celocia argentea & 3.56 & 3.61 & 5.29 & 3.99 & 3.56 & 4.85 & 0.78 & 0.88 & 0.65 & 0.74 & 0.74 & 0.68 \\
\hline Crotolaria prostrate & 4.07 & 3.61 & 2.65 & 4.55 & 3.56 & 2.42 & 0.69 & 0.77 & 0.52 & 0.71 & 0.8 & 1.01 \\
\hline Desmodium triflorum & 4.83 & 3.89 & 5.29 & 3.99 & 3.56 & 6.06 & 0.77 & 0.88 & 0.7 & 0.61 & 0.73 & 0.61 \\
\hline Evolvulus alsenoides & 3.82 & 3.89 & 3.7 & 4.26 & 4.15 & 3.64 & 0.25 & 0.24 & 0.19 & 0.26 & 0.27 & 0.18 \\
\hline Evolvulus numularis & 3.31 & 3.33 & 1.59 & 3.72 & 3.56 & 1.82 & 0.3 & 0.27 & 0.05 & 0.29 & 0.2 & 0.21 \\
\hline Phyllanthus virgatus & 4.07 & 3.89 & 1.59 & 3.19 & 2.67 & 1.21 & 3.41 & 1.6 & - & 3.03 & 1.88 & - \\
\hline Sida acuta & 3.05 & 3.33 & 1.59 & 2.93 & 3.56 & 1.21 & 0.21 & 0.23 & 0.39 & 0.41 & 0.17 & 0.09 \\
\hline Spermacoce hipsida & 4.07 & 4.17 & 5.29 & 4.26 & 4.15 & 6.06 & 0.36 & 0.39 & 0.031 & 0.43 & 0.38 & 0.12 \\
\hline Vernonia cinerea & 3.05 & 2.78 & 1.06 & 3.72 & 2.97 & 1.21 & 0.26 & 0.22 & 0.13 & 0.26 & 0.27 & 0.21 \\
\hline Zornia gibbose & 4.07 & 3.89 & - & 3.72 & 3.26 & - & 3.62 & 2.05 & - & 3.7 & 2.25 & - \\
\hline
\end{tabular}

$\mathrm{R}=$ Rainy, $\mathrm{W}=$ winter and $\mathrm{S}=$ summer.

2006). The seasonal variation of relative frequency, relative density and relative dominance of different species fluctuated (Tables 2 and 3 ). The majority was from the species Aristida; the next two in order of dominance were Heteropogon and Setaria. Considering the individual species, it is clear that species composition 
Table 3. Seasonal variation of relative dominance and importance value index of plant species at the study sites.

\begin{tabular}{|c|c|c|c|c|c|c|c|c|c|c|c|c|}
\hline \multirow{3}{*}{ Plant species } & \multicolumn{6}{|c|}{ Relative dominance } & \multicolumn{6}{|c|}{ Important value index } \\
\hline & \multicolumn{3}{|c|}{ Site1 } & \multicolumn{3}{|c|}{ Site2 } & \multicolumn{3}{|c|}{ Site1 } & \multicolumn{3}{|c|}{ Site2 } \\
\hline & $\mathbf{R}$ & $\mathbf{W}$ & s & $\mathbf{R}$ & W & $\mathrm{s}$ & $\mathbf{R}$ & $\mathbf{W}$ & s & $\mathbf{R}$ & $\mathbf{W}$ & S \\
\hline Aristida setacea & 7.67 & 8.16 & 13.70 & 7.9 & 8.48 & 14.6 & 29.3 & 33.68 & 62.63 & 31.73 & 38.63 & 68.98 \\
\hline Bothriochloa pertusa & 4.36 & 4.46 & 6.69 & 4.47 & 4.59 & 6.96 & 13.48 & 14.33 & 22.46 & 13.92 & 15.80 & 24.91 \\
\hline Chrysopogon aciculatus & 4.28 & 3.89 & 5.22 & 3.59 & 3.79 & 4.87 & 10.4 & 9.99 & 14.59 & 9.6 & 9.82 & 14.28 \\
\hline Cynodon dactylon & 2.05 & 1.71 & 2.12 & 1.93 & 1.7 & 1.57 & 10.65 & 10.24 & 8.95 & 10.55 & 10.33 & 6.42 \\
\hline Cyperus rotundus & 2.57 & 2.85 & 4.73 & 2.63 & 2.79 & 4.35 & 10.9 & 10.33 & 6.94 & 10.63 & 9.95 & 7.38 \\
\hline Cyperus nivenus & 2.4 & 2.47 & 3.59 & 2.45 & 2.5 & 3.13 & 9.81 & 9.44 & 6.84 & 9.45 & 9.92 & 6.33 \\
\hline Digitaria ciliaris & 3.42 & 3.23 & 3.0 & 3.51 & 2.99 & 2.2 & 9.36 & 8.18 & 3.14 & 9.29 & 7.77 & 3.04 \\
\hline Eragrostis gangetica & 4.02 & 3.98 & 5.87 & 3.94 & 3.89 & 5.57 & 11.29 & 11.45 & 11.65 & 11.51 & 12.8 & 10.93 \\
\hline Heteropogon contortus & 5.13 & 5.5 & 8.48 & 4.91 & 5.39 & 8.17 & 28.13 & 24.71 & 43.64 & 28.97 & 32.22 & 41.71 \\
\hline Panicum repens & 6.16 & 6.45 & - & 5.61 & 5.89 & - & 14.04 & 13.51 & - & 14.54 & 14.39 & - \\
\hline Setaria pumila & 4.45 & 4.55 & 7.01 & 4.56 & 4.69 & 6.78 & 27.41 & 30.71 & 25.81 & 25.7 & 25.67 & 20.81 \\
\hline Sporobolus indicus & 4.88 & 5.03 & 4.5 & 4.91 & 5.29 & 4.5 & 17.03 & 14.94 & 4.47 & 15.2 & 13.97 & 5.5 \\
\hline Andrographis echioides & 4.28 & 4.27 & 6.69 & 4.38 & 4.39 & 6.78 & 9.75 & 10.27 & 15.88 & 9.86 & 10.77 & 12.07 \\
\hline Cassia tora & 5.99 & 5.5 & 5.4 & 6.13 & 5.69 & 5.35 & 11.56 & 10.72 & 6.35 & 11.46 & 9.72 & 6.06 \\
\hline Celocia argentea & 4.28 & 4.55 & 6.53 & 4.38 & 4.69 & 6.26 & 8.62 & 9.05 & 12.46 & 9.11 & 8.99 & 11.79 \\
\hline Crotolaria prostrate & 5.05 & 5.12 & 4.5 & 5.17 & 5.19 & 4.8 & 9.81 & 9.51 & 3.16 & 10.14 & 9.55 & 3.43 \\
\hline Desmodium triflorum & 3.68 & 3.61 & 3.5 & 3.77 & 3.69 & 3.48 & 9.29 & 8.38 & 5.99 & 8.37 & 7.98 & 6.67 \\
\hline Evolvulus alsenoides & 4.36 & 4.36 & 6.85 & 4.38 & 4.19 & 6.61 & 8.43 & 8.5 & 10.55 & 8.9 & 8.61 & 10.24 \\
\hline Evolvulus numularis & 2.14 & 1.8 & 2.45 & 2.19 & 1.7 & 3.83 & 5.74 & 5.4 & 4.08 & 6.2 & 5.46 & 5.64 \\
\hline Phyllanthus virgatus & 3.68 & 3.51 & - & 3.77 & 3.49 & - & 11.16 & 8.99 & 1.59 & 9.99 & 8.04 & 1.21 \\
\hline Sida acuta & 3.76 & 3.7 & 5.71 & 3.86 & 3.79 & 5.22 & 7.02 & 7.56 & 7.68 & 7.19 & 7.52 & 6.51 \\
\hline Spermacoce hipsida & 4.28 & 4.27 & 6.36 & 4.47 & 4.19 & 5.91 & 8.71 & 8.83 & 11.68 & 9.13 & 8.73 & 11.97 \\
\hline Vernonia cinerea & 5.22 & 5.41 & 7.99 & 5.26 & 5.39 & 7.65 & 8.53 & 8.41 & 9.18 & 9.26 & 8.62 & 9.08 \\
\hline Zornia gibbose & 1.88 & 1.61 & - & 1.84 & 1.6 & - & 9.58 & 7.55 & - & 9.26 & 7.11 & - \\
\hline
\end{tabular}

$\mathrm{R}=$ Rainy, $\mathrm{W}=$ winter and $\mathrm{S}=$ summer.

Table 4. Dominance and diversity indices of species at the study sites.

\begin{tabular}{lcccccc}
\hline \multirow{2}{*}{ Parameter } & \multicolumn{3}{c}{ Site1 } & \multicolumn{2}{c}{ Site 2 } \\
\cline { 2 - 7 } & Rainy & Winter & Summer & Rainy & Winter & Summer \\
\hline Dominance index & 0.188 & 0.212 & 0.446 & 0.262 & 0.28 & 0.536 \\
Diversity index & 1.597 & 1.578 & 0.845 & 2.42 & 2.397 & 0.886 \\
\hline
\end{tabular}

in plantation site greatly differed from plantation with crusher units. The grass species have more IVI values as compared to non-grass species in the community. Aristida setacea and Evolvulus numularis contributed maximum and minimum IVI value for both sites. However, Phyllanthus virgatus showed the minimum IVI in summer season. It was also observed that the IVI value in total for all grass species gradually increased from rainy to summer season whereas the non-grasses value showed reverse trend. The value of relative frequency, density, dominance and important value index was found to coincide with the findings of Misra (1978), Pradhan (1994) and Mishra and Mishra (1981). The value of Simpson's dominance index varied from 0.188 to 0.536 . It showed increasing trend from rainy to summer having highest value in summer. In contrast, the diversity index showed decreasing trend from rainy to summer. The highest value of Shannon diversity index (2.42) was in site with crusher units and the lowest value (0.845) was in site without crusher units. The variability of index value in the present study may be due to the action of crusher dust upon the vegetation. The trend of different indices in the present study corroborates with the findings of Pradhan (1994), Misra and Misra (1981). It is concluded that the crusher dusts influence the floristic composition and biological spectrum of the grassland 


\section{adjacent to crusher units.}

\section{REFERENCES}

Barik KL, Misra BN (1998). Biological spectrum of a grassland ecosystem of South Orissa. Ecoprint 5(1):73-77.

Chatter, $H$ (1991). Effect of Cement dust on the enzymatic activity in the levels of Triticum aestivum. Acta Ecol. 13:113-119.

Chowdhary U, Rao TVR (1996). Effect of cement dust on the enzymatic activity in the levels of Triticum aestivum. Acta Ecol. 13:113-119.

Daniels RRJ, Jayanthi M (1996). Biology and conservation of endangered plants: the need to study breeding systems. Trop. Ecol. 37:39-42.

Ekka NJ, Behera N (2011). Under storey plant diversity analysis on different age series coal mine spoil dumps in an open cast coal field in Orissa, India. Trop. Ecol. 52(3):373-343.

Ezeaku PI, Davidson A (2008). Analytical situations of land degradation and sustainable management strategies in Africa. J. Agric. Soc. Sci. 4:42-52.

Gupta S, Narayan R (2010). Brick Kiln industry in Long term impacts biomass and diversity structure of plant communities. Curr. Sci. 99(1):72-77.

Helm, DJ (1995). Native grass cultivars for multiple revegetation goals on a proposed mine site in South Central Alaska. Restor. Ecol. 3(2):111-122.

Jain SK (1991). The problems of endangered species, concepts, problems and solutions. In: Singh KP, Singh JS (eds.).Tropical ecosystems: Ecology and Management. Willey Eastern, New Delhi, India, pp. 69-80.

Kumar RR, Shadaksharasamy N, Srinivas G (2000). Impacts of granite quarrying on environment in Banglore district with reference to socioeconomic status of workers. Pollut. Res. 19:51-54.

Lal R (1989). Soil degradation and conversion of tropical rain forest. In: Botkin, DB, Caswell, MF, Estes, JE, Orio, AA (eds.).Changing the global environment. New York: Academic Press, pp. 135-153.

Lalrammawia C, Paliwal K (2010). Seasonal changes in net ecosystem change of $\mathrm{CO}_{2}$ and respiration of Cenchrus ciliaris L. grassland ecosystem in semiarid tropics: An eddy covariance measurement. Curr. Sci. 98(9):1211-1218.

Ludwig JA, Reynolds JF (1988). Statistical ecology. New York: John Wiley.

Mishra JV, Pandey SN, Singh N, Singh MY, Ahmed KJ (1993). Growth response of Lycopersicum esculentum to cement dust treatment. J. Environ. Sci. Health 28:1774-1780.

Mishra MK, Mishra BN (1981). Species diversity and dominance in a tropical grassland community. Folia Geobotanica et Phytotaxonomica 16(3):309-316.

Mishra R (1968): Ecological Work Book. Oxford and I.B.H. Publishing Co., New Delhi.

Misra MK (1978). Phytosociology and primary production of a grassland community of Berhampur. Ph.D. Thesis, Berhampur University, Berhampur, Orissa.

Mroz GD, Jurgensen MF, Federick DJ (1985). Soil nutrient changes following whole tree harvesting on tree -northern hard wood sites. Soil Soc Sci. Am. 49:1552-1557.
Okita T, Hara H, Fukuzaki N (1996). Measurements of atmospheric $\mathrm{SO}_{2}$ and $\mathrm{SO}_{4}{ }^{2-}$ and determination of the wet scavenging coefficient of Sulfate aerosols for the winter monsoon season over the Sea of Japan. Atmos. Environ. 30:3733-3739.

Pandey DD, Nand S (1995). Effect of stone crushers dust pollution on grain characteristic of Maize. Environ. Ecol. 13:901-903.

Pandey JS, Khan S, Joseph V, Kumar R (2002). Aerosol scavenging: Model application and sensitivity analysis in the Indian context. Environ. Monit. Assess. 74:105-116.

Pandey S, Maiti T (2008). Physicochemical and biological characterization of slag disposal site at Burnpur, West Bengal. Pollut. Res. 27(2):345-348.

Phillips EA (1959): Methods of Vegetation Study. A Hoff Dryden Book, Henry Holt Co. Inc., New York.

Prach K, Bartha S, Joyee CB, Pyšek P, Van Diggelen R, Wiegleb G (2001). Role of spontaneous succession in ecosystem restoration: A perspective. Appl. Veget. Sci. 4:111-114.

Pradhan D (1994). Primary production and phytosociology of a grassland community of Bhubaneswar. Ph.D. Thesis, Berhampur University, Berhampur, Orissa.

Pyšek A, Pyšek P, Jarošík V, Hájek M, Wild J (2003). Diversity of native and alien plant species on rubbish dumps: Effects of dump age, environmental factors and toxicity. Divers .Distrib. 9:177-189.

Raina AK, Rathore V, Sharma A (2008). Effect of stone crusher dust on leaves Melia azadarach L. and Dalbergia sissoo Roxb. in Jammu (J\&K). Nat. Environ. Pollut. Technol. 7:279-282.

Raunkiaer C (1937). The life forms of plants and statistical plant geography.Clarendon Press, Oxford. pp. 639.

Remon E, Bouchardon JL, Cornier B, Guy B, Leclerc JC, Faure O (2005). Soil characteristics, heavy metal availability and vegetation recovery at a former metallurgical landfill: Implications in risk assessment and site restoration. Environ. Pollut. 137:316-323.

Roy A, Basu SK, Singh KP (2002). Modeling ecosystem development on blast furnace slag dumps in a tropical region. Simulation 78(9):531-542.

Singh A (2006). Herbaceous species com position of an age series of naturally revegetated coal mine spoils on Singrauli Coalfields. India. J. Indian Inst. Sci. 86:76-80.

Somashekar RK, Ravi R, Ramesh AM (1999). Impact of granite mining on some plant species around quarries and crusher of Bangalore district. Pollut. Res. 18:445-451.

Srivastava A, Joseph AE, Patil S, More A, Dixit RC, Prakash M (2005). Air toxics in ambient air of Delhi. Atmos. Environ. 39:59-71. 